\title{
Biomass and carbon stocks in mangrove stands of Kadalundi estuarine wetland, south-west coast of India
}

\author{
K. VINOD, A. ANASU KOYA, V. A. KUNHI KOYA, P. G. SILPA, P. K. ASOKAN, P. U. ZACHARIA* \\ AND K. K. JOSHI* \\ ICAR-Central Marine Fisheries Research Institute, Calicut Research Centre, West Hill (P.O.), Calicut - 673005 \\ Kerala, India \\ ${ }^{*}$ Central Marine Fisheries Research Institute, Ernakulam North P. O., Kochi - 682 018, Kerala, India \\ e-mail:vinod_kavungal@yahoo.co.in
}

\begin{abstract}
Mangroves are keystone ecosystems which provide numerous environmental services. Mangroves assume significance as standing stores of sequestered atmospheric carbon and are therefore, important in the light of climate change mitigation. In this study, we attempted to assess the biomass of mangroves in the Kadalundi wetland, south-west coast of India and evaluated the potential of these mangroves to sequester and store carbon. The C-stocks of above-ground and root biomass were $83.32 \pm 11.06 \mathrm{t} \mathrm{C} \mathrm{ha}^{-1}$ and $34.96 \pm 4.30 \mathrm{t} \mathrm{C} \mathrm{ha}^{-1}$ respectively, while the $\mathrm{C}$-stock in sediment was estimated to be $63.87 \pm 8.67 \mathrm{t} \mathrm{C} \mathrm{ha}^{-1}$. The estimates of mean combined $\mathrm{C}$-stocks in the mangrove biomass and sediment of Kadalundi shows that this estuarine mangrove wetland stored $182.15 \mathrm{t} \mathrm{C} \mathrm{ha}^{-1}$, which was equivalent to $668.48 \mathrm{t} \mathrm{CO}_{2} \mathrm{ha}^{-1}$. The mangroves which cover an area of 13.23 ha in the Kadalundi wetland is assumed to have a potential to sequester and store a substantial quantity of 2,409.84 $\mathrm{t} \mathrm{C}$ which is equivalent to $8,844.11 \mathrm{t} \mathrm{CO}_{2}$. The study underscores the importance of these intertidal forests for climate change mitigation and stresses the importance of protecting the mangroves which provide many other important ecosystem services that benefit communities.
\end{abstract}

Keywords: Carbon sequestration, Carbon stocks, Mangroves, Tree biomass

\section{Introduction}

Mangroves are keystone ecosystems providing numerous environmental services and critical ecological functions. They thrive along the coastlines in most of the tropical and sub-tropical regions. These ecosystems are highly productive and rich in floral and faunal biodiversity. They are home to many aquatic species and it is well known that most of the commercially important fin and shellfish species spend at least part of their life cycle in these ecosystems which serve as an important breeding and nursery ground. Mangroves play an important role in supporting coastal food webs and nutrient cycles in the adjacent coastal ecosystems (Robertson and Phillips, 1995; Rivera-Monroy et al., 1999; Alongi et al., 2000; Machiwa and Hallberg, 2002; Mumby et al., 2004). These ecosystems contribute to coastal protection (Field, 1995), commercial fisheries (Barbier, 2000; Diele et al., 2005) and are also highly valued for their aesthetics and ecotourism.

Worldwide, there is an increased awareness among the communities on climate change and its effects. In this context, the forests, including mangroves, assume immense significance as reservoirs of sequestered atmospheric carbon. Murdiyarso et al. (2009), Chen et al. (2012) and Kauffman and Donato (2012) have highlighted the potential role of mangroves in sequestering atmospheric carbon dioxide and to store the sequestered carbon in its biomass as well as in sediments.

The tropical forests are important component in the global carbon cycle and represent $30-40 \%$ of the terrestrial net primary production (Malhi and Grace, 2000; Clark et al., 2001). Although only a mere $0.7 \%$ of tropical forests of the world is contributed by the mangrove forests (Giri et al., 2011), they have the potential to store up to 20 billion $\mathrm{C}$, which is much higher than the mean carbon stock in tropical upland, temperate and boreal forests (Donato et al., 2011). The mangrove forests also contribute remarkably to the carbon biogeochemistry in coastal oceans, by virtue of their exchange with coastal waters (Twilley et al., 1992). Thus, mangroves sequester four times more carbon per unit area than tropical terrestrial forests (Khan et al., 2007; Donato et al., 2011).

Although mangroves have enormous significance, they are one of the most threatened ecosystems, mainly due to human-induced pressures. The reduction in mangrove area leads to loss of potential carbon sinks. 
Also, destruction of these habitats might lead to greater emissions of carbon dioxide back into the air and ocean, which may be much higher than it occurs from terrestrial habitats.

The mangrove carbon pools in the Indo-Pacific region are very high and are more than twice of those of most upland tropical and temperate forests (Kauffman and Donato, 2012). India has a total mangrove cover of 4627.63 sq. $\mathrm{km}$ (FSI, 2013) which is $0.15 \%$ of the country's land area and 3\% of the global mangrove area (Sahu et al., 2016). Considering the potential and area of occurrence in India, substantial amounts of atmospheric carbon dioxide is expected to be sequestered and stored by the mangroves.

The mangroves of Kadalundi forms a part of the Kadalundi-Vallikunnu Community Reserve which is the first Community Reserve of Kerala, India, declared in 2007 and spread across 1.5 sq. $\mathrm{km}$. The study aims to estimate the above-ground and root biomass and C-stocks to understand the blue carbon potential of the mangroves of the Kadalundi wetland in the south-west coast of India.

\section{Materials and methods}

The Kadalundi mangrove wetland comprises five small islands, of which mangrove vegetations are present in four. Hence, the study zone was divided into four sectors, namely, i) Sector I: Balathuruthi I, Sector II: Balathuruthi II, Sector III: Mannanthuruthi and Sector IV: Western side of the railway bridge; all of these sectors have sparse to dense mangrove vegetation (Fig. 1).

\section{Field sampling}

The study was conducted from April 2016 to January 2017. A total of 24 sampling plots (4 in sector I, 5 in sector II, 11 in sector III and 4 in sector IV) each of $10 \mathrm{~m} \times 10 \mathrm{~m}$ size were established through a non-destructive stratified random quadrat sampling technique to determine the composition of mangroves, tree density and carbon stock. The total sampling area covered was 0.24 ha. To mark the exact location of each sampling site, a Global Positioning System, GPS (Garmin GPSmap 76CSx) was used and the spatial location of each quadrat was recorded (Table 1).

\section{Tree measurements}

All the mangrove plants/trees of each study quadrat were measured for their tree girth. The tree girth measurements were taken at breast height, which is approximately $1.3 \mathrm{~m}$ above the ground; and the girth measurements were converted into diameter at breast height (DBH) measurement by dividing by $\pi$ (Frontier Madagascar, 2005). All adult trees as well as saplings greater than $1.3 \mathrm{~m}$ height were considered for measurement of DBH (Fig. 2a). The plants were classified as adults, saplings and seedlings depending on their total height and girth at breast height. The plants greater than $4 \mathrm{~cm}$ girth at breast height and taller than $1 \mathrm{~m}$ were classified as adults. The plants lesser than $4 \mathrm{~cm}$ girth at breast height but taller than $1 \mathrm{~m}$ were classified as saplings while the plants less than $1 \mathrm{~m}$ tall were classified as seedlings (Frontier Madagascar, 2005). In the case of Rhizophora mucronata,

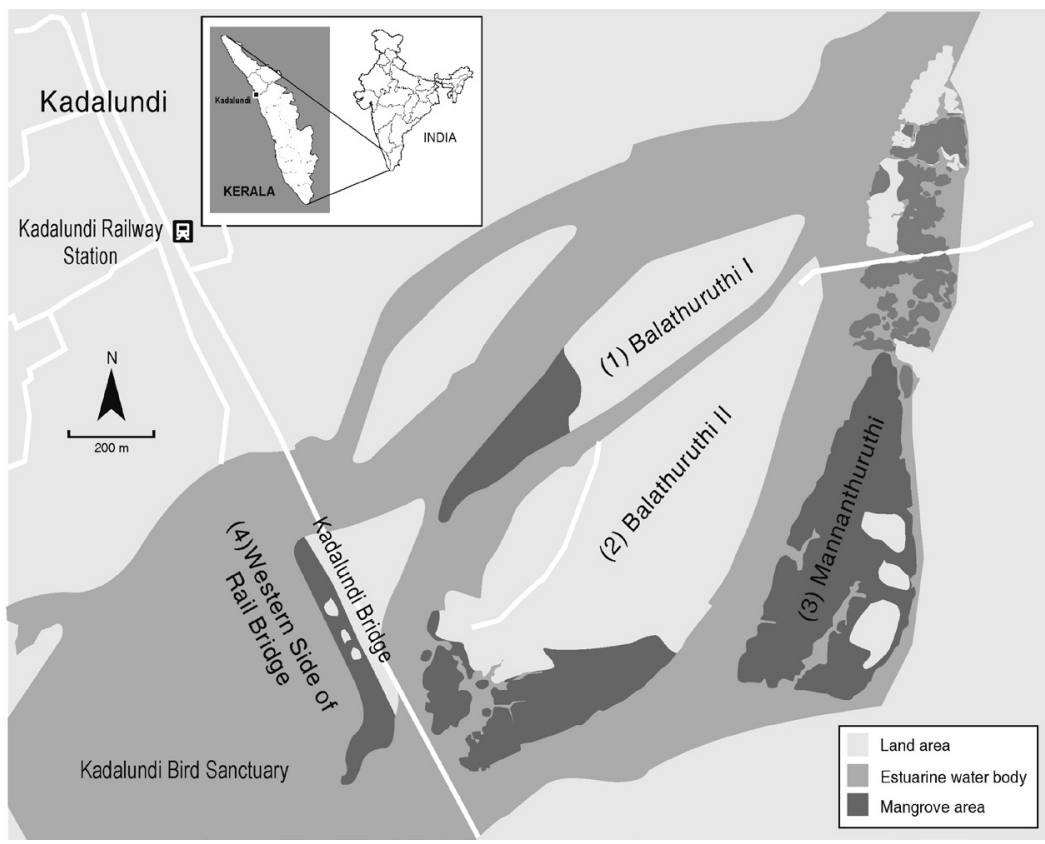

Fig. 1. Map of Kadalundi Estuary showing the study area 
Table 1. Study stations and their geo-spatial locations

\begin{tabular}{|c|c|c|}
\hline Sectors & $\begin{array}{l}\text { Stations/ } \\
\text { Quadrats }\end{array}$ & GPS locations \\
\hline Sector I & 1 & $11^{\circ} 07^{\prime} 52.86^{\prime \prime N} ; 75^{\circ} 50^{\prime} 2.28^{\prime \prime} \mathrm{E}$ \\
\hline \multirow[t]{3}{*}{ Balathuruthi-I } & 2 & $11^{\circ} 07^{\prime} 52.20^{\prime \prime N} ; 75^{\circ} 50^{\prime} 0.84^{\prime \prime} \mathrm{E}$ \\
\hline & 3 & $11^{\circ} 07^{\prime} 51.42^{\prime \prime N} ; 75^{\circ} 49^{\prime} 58.80^{\prime \prime} \mathrm{E}$ \\
\hline & 4 & $11^{\circ} 07^{\prime} 50.64^{\prime \prime N} ; 75^{\circ} 49^{\prime} 59.52^{\prime \prime} \mathrm{E}$ \\
\hline \multirow{5}{*}{$\begin{array}{l}\text { Sector II } \\
\text { Balathuruthi-II }\end{array}$} & 1 & $11^{\circ} 07^{\prime} 38.70^{\prime \prime N} ; 75^{\circ} 50 ’ 2.22^{\prime \prime} \mathrm{E}$ \\
\hline & 2 & $11^{\circ} 07^{\prime} 40.86^{\prime \prime N} ; 75^{\circ} 50^{\prime} 4.50^{\prime \prime} \mathrm{E}$ \\
\hline & 3 & $11^{\circ} 07^{\prime} 39.48^{\prime \prime N} ; 75^{\circ} 49^{\prime} 56.88^{\prime \prime} \mathrm{E}$ \\
\hline & 4 & $11^{\circ} 07^{\prime} 36.78^{\prime \prime} \mathrm{N} ; 75^{\circ} 49^{\prime} 58.80^{\prime \prime} \mathrm{E}$ \\
\hline & 5 & $11^{\circ} 07^{\prime} 39.30^{\prime \prime N} ; 75^{\circ} 49^{\prime} 57.90^{\prime \prime} \mathrm{E}$ \\
\hline \multirow{11}{*}{$\begin{array}{l}\text { Sector III } \\
\text { Mannanthuruthi }\end{array}$} & 1 & 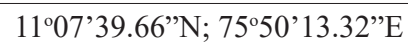 \\
\hline & 2 & $11^{\circ} 07^{\prime} 39.48^{\prime \prime} \mathrm{N} ; 75^{\circ} 50^{\prime} 14.10^{\prime \prime} \mathrm{E}$ \\
\hline & 3 & $11^{\circ} 07^{\prime} 41.52^{\prime \prime N} ; 75^{\circ} 50^{\prime} 13.98^{\prime \prime} \mathrm{E}$ \\
\hline & 4 & $11^{\circ} 07^{\prime} 44.64^{\prime \prime} \mathrm{N} ; 75^{\circ} 50^{\prime} 15.60^{\prime \prime} \mathrm{E}$ \\
\hline & 5 & $11^{\circ} 07^{\prime} 44.04^{\prime \prime} \mathrm{N} ; 75^{\circ} 50^{\prime} 17.10^{\prime \prime} \mathrm{E}$ \\
\hline & 6 & $11^{\circ} 07^{\prime} 46.98^{\prime \prime N} ; 75^{\circ} 50^{\prime} 17.34^{\prime \prime} \mathrm{E}$ \\
\hline & 7 & $11^{\circ} 07^{\prime} 39.18^{\prime \prime N} ; 75^{\circ} 50^{\prime} 16.86^{\prime \prime} \mathrm{E}$ \\
\hline & 8 & $11^{\circ} 07^{\prime} 53.52^{\prime \prime N} ; 75^{\circ} 50 ’ 21.42^{\prime \prime} \mathrm{E}$ \\
\hline & 9 & $11^{\circ} 07^{\prime} 48.90^{\prime \prime} \mathrm{N} ; 75^{\circ} 50^{\prime} 22.08^{\prime \prime} \mathrm{E}$ \\
\hline & 10 & $11^{\circ} 07^{\prime} 39.12^{\prime \prime N} ; 75^{\circ} 50^{\prime} 19.44^{\prime \prime} \mathrm{E}$ \\
\hline & 11 & $11^{\circ} 07^{\prime} 45.36^{\prime \prime N} ; 75^{\circ} 50 ’ 21.06^{\prime \prime} \mathrm{E}$ \\
\hline \multirow{4}{*}{$\begin{array}{l}\text { Sector IV } \\
\text { Western side of } \\
\text { railway bridge }\end{array}$} & 1 & $11^{\circ} 07^{\prime} 46.74^{\prime \prime} \mathrm{N} ; 75^{\circ} 49^{\prime} 49.50^{\prime \prime} \mathrm{E}$ \\
\hline & 2 & $11^{\circ} 07^{\prime} 45.18^{\prime \prime} \mathrm{N} ; 75^{\circ} 49^{\prime} 50.28^{\prime \prime} \mathrm{E}$ \\
\hline & 3 & $11^{\circ} 07^{\prime} 39.42^{\prime \prime N} ; 75^{\circ} 49^{\prime} 52.62^{\prime \prime} \mathrm{E}$ \\
\hline & 4 & $11^{\circ} 07^{\prime} 38.64^{\prime \prime N} ; 75^{\circ} 49^{\prime} 52.74^{\prime \prime} \mathrm{E}$ \\
\hline
\end{tabular}

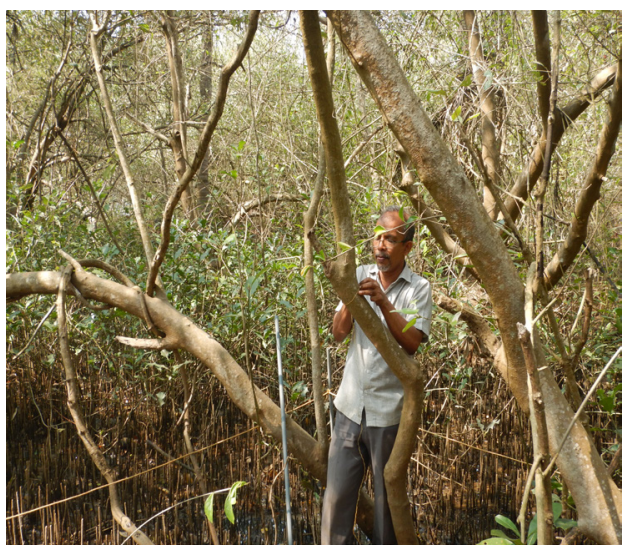

(a) (e.g. seedlings and herbs) is generally negligible in mangroves and its measurement for ecosystem carbon pools need not be considered (Kauffman and Donato, 2012). Also, litter being a small component of the total ecosystem, carbon stock is not usually sampled (Kauffman and Donato, 2012). All the dead trees were also taken into consideration and the biomass of standing dead trees were estimated based on the decay status categories following the methods suggested by Kauffman and Donato (2012).

\section{Estimation of biomass and carbon stock}

Three pools of carbon were taken into consideration for the measurement of carbon stored in mangrove ecosystem viz., i) above-ground biomass, ii) below-ground biomass (root) and iii) sediment. The allometric equations developed by Komiyama et al. (2005) for mangroves of south-east Asia were used for the estimation of above-ground biomass $\left(\mathrm{W}_{\text {top }}\right)$ and below-ground biomass $\left(\mathrm{W}_{\mathrm{R}}\right)$. The allometric equations are:

$$
\begin{aligned}
& \mathrm{W}_{\text {top }}=0.251 \rho \mathrm{D}^{2.46} \\
& \mathrm{~W}_{\mathrm{R}}=0.199 \rho^{0.899} \mathrm{D}^{2.22}
\end{aligned}
$$

where $\mathrm{W}_{\text {top }}$ is the above-ground biomass $(\mathrm{kg}), \mathrm{W}_{\mathrm{R}}$ is the below-ground biomass (root), $\rho$ is the wood density of the respective species and $\mathrm{D}$ is the diameter at breast height $(\mathrm{DBH})$

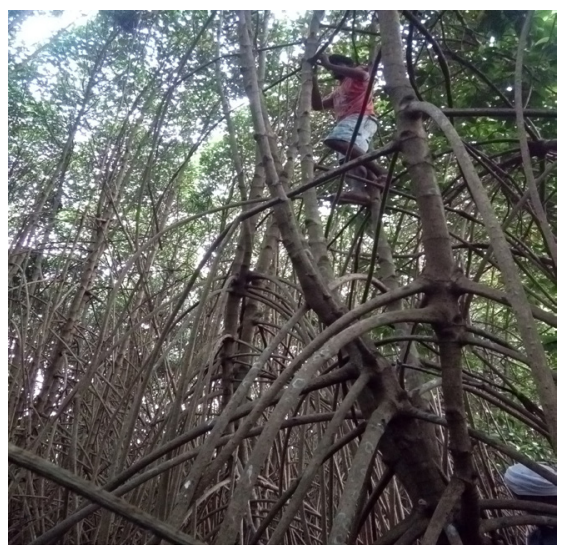

(b)

Fig. 2. DBH measurements of (a) Avicennia officinalis - $1.3 \mathrm{~m}$ from the ground and (b) Rhizophora mucronata $-30 \mathrm{~cm}$ above the highest prop root

which is characterised by the presence of prop roots, the trunk diameter at $30 \mathrm{~cm}$ above the highest prop root was measured (Komiyama et al., 2005) (Fig. 2b).

All the adult trees lying in each quadrat were considered for measurement of above and below ground biomass as well as carbon stock. The understory vegetation
The wood density of different mangrove species was obtained from the World Agroforestry Database (WFC, 2011)

The value of above-ground and below-ground biomass was summed up to get the total biomass for all the plots which were then averaged to get the mean total 
biomass and finally converted to tons per hectare. The carbon values were estimated as $50 \%$ of the biomass (Komiyama et al., 2005).

\section{Soil sampling and analysis}

The soil samples were collected from each quadrat using a PVC core having a length of $1 \mathrm{~m}$ and radius of $2 \mathrm{~cm}$. The soil samples from surface to $30 \mathrm{~cm}$ depth were collected from each core sampling and stored in clean polythene bags for the estimation of organic carbon. Simultaneously, another set of core sample was collected from the same plot for estimating the sediment bulk density. The bulk density was calculated using dry weight (oven-dried) of the core sample divided by the volume of core. The organic carbon in soil samples were estimated following the method of Walkley and Black (1934). The soil organic carbon per hectare was determined using the formula:

Soil organic Carbon $\left(\mathrm{t} \mathrm{ha}^{-1}\right)=$ Bulk density $\left(\mathrm{g} \mathrm{cm}^{-3}\right) \times$ Soil depth $(\mathrm{cm})$ x Organic carbon $(\%)$

\section{Results}

\section{Floristic composition}

A total of six species of mangroves viz., Avicennia officinalis (Family: Avicenniaceae), Rhizophora mucronata (Family: Rhizophoraceae), Sonneratia alba (Family: Lythraceae), Bruguiera cylindrica (Family: Rhizophoraceae), Excoecaria agallocha (Family: Euphorbiaceae) and Acanthus ilicifolius (Family: Acanthaceae) which belonged to 6 genera and 5 families were recorded from the Kadalundi mangrove wetland. The composition of mangrove species in different sectors of the study area is given in Table 2 .

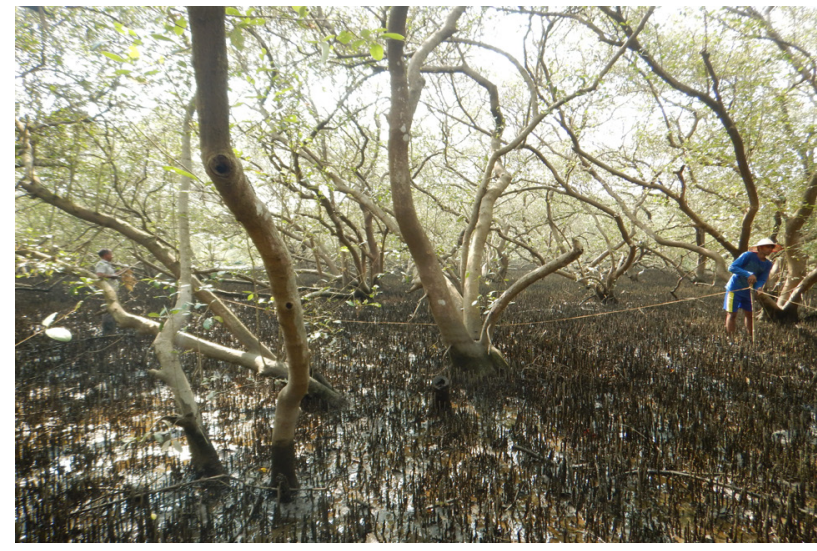

Fig. 3. Dominant Avicennia officinalis in Kadalundi mangrove wetland

Sector I, Balathuruthi-I: is a small island with patchy to dense mangroves dominated by $A$. officinalis and fringed by $A$. ilicifolius in the peripheral region. This island has mangrove vegetation in 1.59 ha and the rest of the area has coconut plantations and residential houses. The mangroves were also found to extend towards some of the coconut planted areas.

Sector II, Balathuruthi-II: The total mangrove area of Balathuruthi-II is 3.22 ha with A. officinalis being the predominant mangrove species. This sector was characterised by a dense patch of $R$. mucronata along the western side (Fig. 4). This island has maximum number of inhabitants with over one hundred houses spread from the mid to the eastern part of the island.

Table 2. Floristic composition of mangroves in different sectors of the study area

\begin{tabular}{lllll}
\hline \multirow{2}{*}{ Species } & \multicolumn{3}{c}{ Sectors } \\
\cline { 2 - 5 } & Sector I & Sector II & Sector III & Sector IV \\
\hline Avicennia officinalis & Balathuruthi I & Balathuruthi II & Mannanthuruthi & West of the railway bridge \\
Rhizophora mucronata & $\sqrt{ }$ & $\sqrt{ }$ & $\sqrt{ }$ & $\sqrt{ }$ \\
Bruguiera cylindrica & $\mathrm{x}$ & $\sqrt{ }$ & $\sqrt{ }$ & $\sqrt{ }$ \\
Sonneratia alba & $\sqrt{ }$ & $\mathrm{x}$ & $\mathrm{V}$ & $\mathrm{x}$ \\
Excoecaria agallocha & $\mathrm{x}$ & $\mathrm{x}$ & $\sqrt{ }$ & $\sqrt{ }$ \\
Acanthus ilicifolius & $\sqrt{ }$ & $\sqrt{ }$ & $\sqrt{ }$ & $\sqrt{ }$ \\
\hline
\end{tabular}

$\sqrt{ }$ - Present; $x$ - Absent

Among the six species, $A$. officinalis was the predominant species in terms of number as well as in terms of coverage of area (Fig. 3). S. alba, which is a planted vegetation, formed only a small patch near the railway bridge (sector IV). A. ilicifolius formed a fringe in some islands, but also formed dense patches in other areas. B. cylindrica and E. agallocha occurred in less numbers and in small areas in the entire Kadalundi mangrove ecosystem.
Sector III, Mannanthuruthi: This island is the largest with an approximate mangrove area of 7.39 ha. Except for $S$. $a l b a$, all other mangrove species recorded in the Kadalundi mangrove wetland during the present study were found in this sector. However, the dominant species of this sector was A. officinalis. There were three small patches of coconut plantations; however, there are no inhabitants in Mannanthuruthi. 


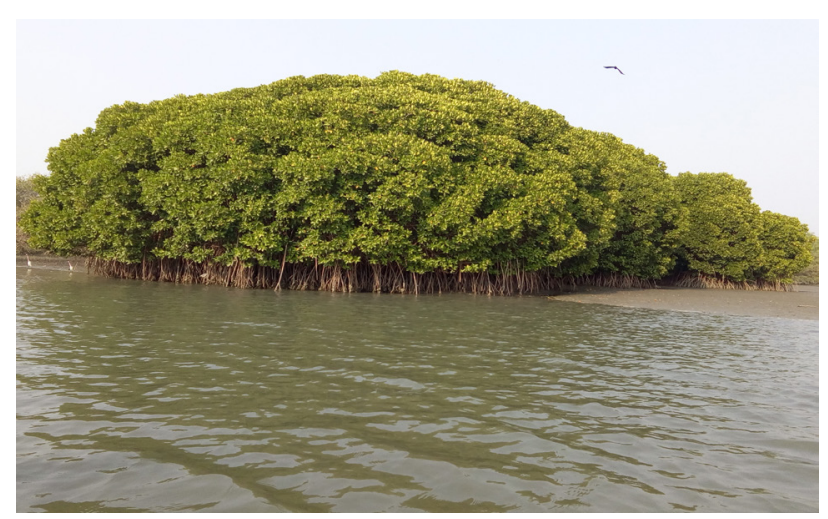

Fig. 4. Dense patch of Rhizophora mucronata in Balathuruthi Island

Sector IV, Western side of Railway Bridge: Patchy to dense mangroves occur in this small area of 1.03 ha which lies very close to the estuarine bar mouth. The mangrove $A$. officinalis occupied about $50 \%$ of the area and the remaining $50 \%$ comprised of $S$. alba of different sizes. In this sector, A. officinalis is a natural mangrove while $S$. alba is a planted one and in between, A. ilicifolius is also found.

Tree density and diameter at breast height (DBH)

A total of 694 individual stems (662 live and 32 dead) were recorded and studied from 0.24 ha of sampling area. In the case of $A$. officinalis, the average tree density was the highest (1300 individuals ha-1). The density of $R$. mucronata and B. cylindrica were 220 and 270 individuals $\mathrm{ha}^{-1}$, respectively, while that of $S$. alba was 146 individuals ha ${ }^{-1}$. E. agallocha showed the lowest density of 42 individuals ha-1 (Fig. 5).

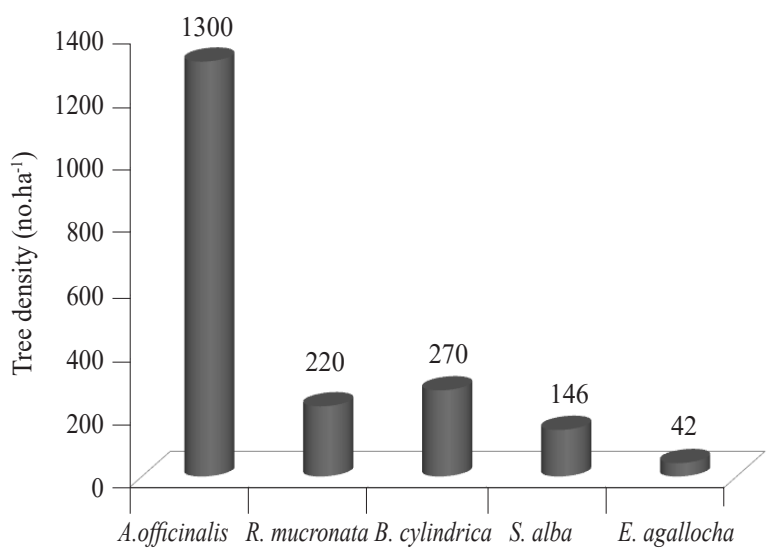

Fig. 5. Mangrove tree density in the Kadalundi Estuary

DBH of different mangrove species ranged from $3.89 \pm 2.26$ (B. cylindrica) to $10.01 \pm 7.07 \mathrm{~cm}$ (A. officinalis). DBH of E. agallocha was $6.09 \pm 5.14 \mathrm{~cm}$, while that of R. mucronata and $S$. alba were $5.61 \pm 2.15$ and $4.59 \pm 2.15 \mathrm{~cm}$ respectively (Fig. 6).

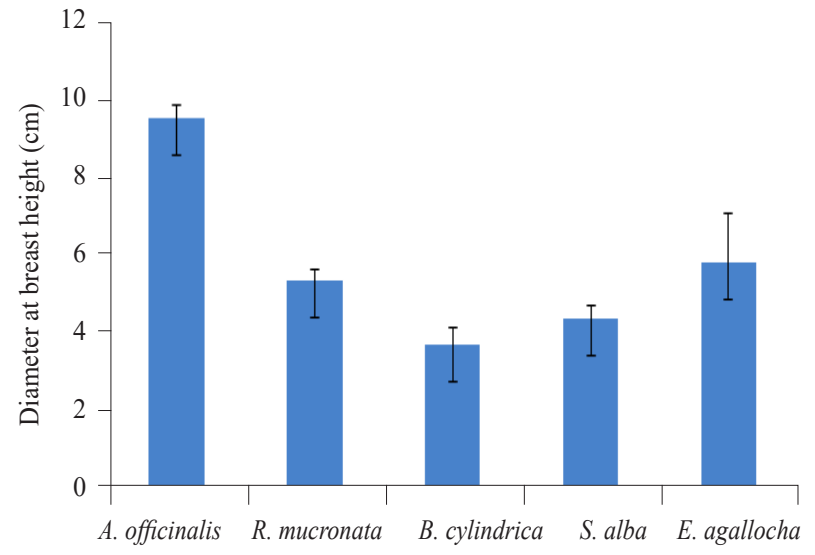

Fig. 6. Average diameter at breast height (DBH) of different mangrove species in the Kadalundi Estuary (Vertical bars denote SE)

\section{Biomass and C-stock}

Table 3 shows species-wise comparison of the mean above ground biomass (AGB), root biomass and the total biomass. The highest biomass of $196.48 \pm 31.69 \mathrm{t} \mathrm{ha}^{-1}$ (AGB of $140.05 \pm 23.25 \mathrm{tha}^{-1}$ and root biomass of $\left.56.43 \pm 8.51 \mathrm{tha}^{-1}\right)$ was recorded in A. officinalis, being the dominant species of the Kadalundi mangrove wetland, while the lowest biomass of $1.67 \pm 1.10 \mathrm{t} \mathrm{ha}^{-1}$ was recorded in B. cylindrica.

Among the Kadalundi mangroves, the species that contributed most to the total carbon was $A$. officinalis $\left(98.24 \pm 15.85 \mathrm{tha}^{-1}\right)$, followed by $R$. mucronata $\left(17.01 \mathrm{tha}^{-1}\right)$. The total carbon share of $S$. alba $\left(1.21 \pm 0.86 \mathrm{t} \mathrm{ha}^{-1}\right)$, E. agallocha $\left(0.98 \pm 0.72 \mathrm{t} \mathrm{ha}^{-1}\right)$ and $B$. cylindrica $\left(0.84 \pm 0.55 \mathrm{t} \mathrm{ha}^{-1}\right)$ were less due to their sparse distribution and less density in Kadalundi (Table 4).

Table 5 provides the summary of biomass and carbon stocks of mangroves in different sectors of the study area at Kadalundi. The AGB ranged from 89.39 (sector IV) to 283.15 t ha $^{-1}$ (sector I), with an overall mean AGB value of $166.63 \mathrm{t} \mathrm{ha}^{-1}$, while the above-ground carbon ranged from 44.69 (sector IV) to $141.58 \mathrm{t} \mathrm{C} \mathrm{ha}^{-1}$ (sector I), with an overall mean carbon value of $83.32 \mathrm{t} \mathrm{C} \mathrm{ha}^{-1}$. The range in estimates of mean root biomass was $37.21 \pm 18.28 \mathrm{t} \mathrm{ha}^{-1}$ (sector IV) to $105.66 \pm 20.53 \mathrm{t} \mathrm{ha}^{-1}$ (sector I) and the C-stock of root biomass ranged from $18.60 \pm 9.14 \mathrm{t} \mathrm{C} \mathrm{ha}^{-1}$ to $52.83 \pm 10.26 \mathrm{t} \mathrm{C} \mathrm{ha}^{-1}$ in different sectors of the study area. The overall mean root biomass was $69.92 \pm 8.61 \mathrm{t} \mathrm{ha}^{-1}$, with a carbon stock of $34.96 \pm 4.30 \mathrm{t} \mathrm{C} \mathrm{ha}^{-1}$.

On the stand level, the Kadalundi mangroves has a total mean biomass of $236.56 \mathrm{t} \mathrm{ha}^{-1}$ ranging from 126.59 to $388.81 \mathrm{t} \mathrm{ha}^{-1}$. The total biomass C-stock varied from 63.30 to $194.41 \mathrm{t} \mathrm{C} \mathrm{ha}^{-1}$ with a mean of $118.28 \mathrm{t} \mathrm{C} \mathrm{ha}^{-1}$. This was equivalent to 232.31 to $713.48 \mathrm{t} \mathrm{CO}_{2} \mathrm{ha}^{-1}$ with an average of $434.09 \mathrm{t} \mathrm{CO}_{2} \mathrm{ha}^{-1}$ which was sequestered and 
Table 3. Biomass of different mangrove species of Kadalundi wetland (overall mean of stations with standard error)

\begin{tabular}{llll}
\hline \multirow{2}{*}{ Species } & \multicolumn{3}{l}{ Biomass $\left(\mathrm{t} \mathrm{ha}^{-1}\right)$} \\
\cline { 2 - 4 } & Above Ground Biomass & Root Biomass & Total Biomass \\
\hline Avicennia officinalis & $140.05 \pm 23.25$ & $56.43 \pm 8.51$ & $196.48 \pm 31.69$ \\
Rhizophora mucronata & $22.59 \pm 15.91$ & $11.44 \pm 8.01$ & $34.03 \pm 23.92$ \\
Bruguiera cylindrica & $1.08 \pm 0.70$ & $0.59 \pm 0.40$ & $1.67 \pm 1.10$ \\
Sonneratia alba & $1.58 \pm 1.12$ & $0.85 \pm 0.60$ & $2.43 \pm 1.72$ \\
Excoecaria agallocha & $1.34 \pm 1.01$ & $0.62 \pm 0.44$ & $1.96 \pm 1.45$ \\
\hline
\end{tabular}

Table 4. Carbon stock of different mangrove species of Kadalundi wetland (overall mean of stations with standard error)

\begin{tabular}{llll}
\hline \multirow{2}{*}{ Species } & \multicolumn{3}{l}{ Carbon $\left(\mathrm{t} \mathrm{ha}^{-1}\right)$} \\
\cline { 2 - 4 } & Above Ground Carbon & Root Biomass Carbon & Total Carbon \\
\hline Avicennia officinalis & $70.02 \pm 11.62$ & $28.22 \pm 4.26$ & $98.24 \pm 15.85$ \\
Rhizophora mucronata & $11.29 \pm 7.95$ & $5.72 \pm 4.01$ & $17.01 \pm 11.96$ \\
Bruguiera cylindrica & $0.54 \pm 0.35$ & $0.30 \pm 0.20$ & $0.84 \pm 0.55$ \\
Sonneratia alba & $0.79 \pm 0.56$ & $0.42 \pm 0.30$ & $1.21 \pm 0.86$ \\
Excoecaria agallocha & $0.67 \pm 0.50$ & $0.31 \pm 0.22$ & $0.98 \pm 0.72$ \\
\hline
\end{tabular}

stored in the above ground and root biomass. The ratio of above-ground biomass and root biomass (referred to as T/R ratio) ranged from 2.22 to 2.68 , with an average value of 2.38. In the case of the Kadalundi mangrove wetland, the above-ground biomass constituted $70.44 \%$ of the total biomass while the remaining $29.56 \%$ accounted for the roots.

\section{Sediment C-stock}

Table 6 summarises the sediment bulk density and the organic carbon pool in the upper $30 \mathrm{~cm}$ depth of the mangrove sediment in different study stations. The mean percentage organic carbon obtained in the present study was 2.62 (range of 1.74 to $3.31 \%$ ). The total soil organic carbon ranged from $40.13 \pm 12.31$ to $76.37 \pm 6.50 \mathrm{t} \mathrm{C} \mathrm{ha}^{-1}$.

\section{Total C-stock}

The estimates of mean combined C-stocks in the mangrove biomass and sediment of Kadalundi showed that this estuarine mangrove wetland stored $182.15 \mathrm{t} \mathrm{C} \mathrm{ha}^{-1}$ (above ground $83.32 \mathrm{t} \mathrm{C} \mathrm{ha}^{-1}$, root $34.96 \mathrm{t} \mathrm{C} \mathrm{ha}^{-1}$ and sediment $63.87 \mathrm{t} \mathrm{C} \mathrm{ha-1}^{-1}$, which was equivalent to $668.48 \mathrm{t} \mathrm{CO}_{2} \mathrm{ha}^{-1}$ (above-ground $305.78 \mathrm{t} \mathrm{CO}_{2} \mathrm{ha}^{-1}$, root $128.30 \mathrm{t} \mathrm{CO}_{2} \mathrm{ha}^{-1}$ and sediment $234.40 \mathrm{t} \mathrm{CO}_{2} \mathrm{ha}^{-1}$ ) (Fig. 7). Of the three carbon pools, the above-ground C-stock was the highest (45.74\%), followed by the carbon stock of sediment $(35.06 \%)$ and the carbon stock of root biomass $(19.20 \%)$.

\section{Discussion}

A. officinalis was the dominant mangrove species in Kadalundi wetland; the average tree density (1300 individuals $\left.\mathrm{ha}^{-1}\right)$ and the $\mathrm{DBH}(10.01 \pm 7.07 \mathrm{~cm})$ values were also the highest in this species. When we compare the DBH

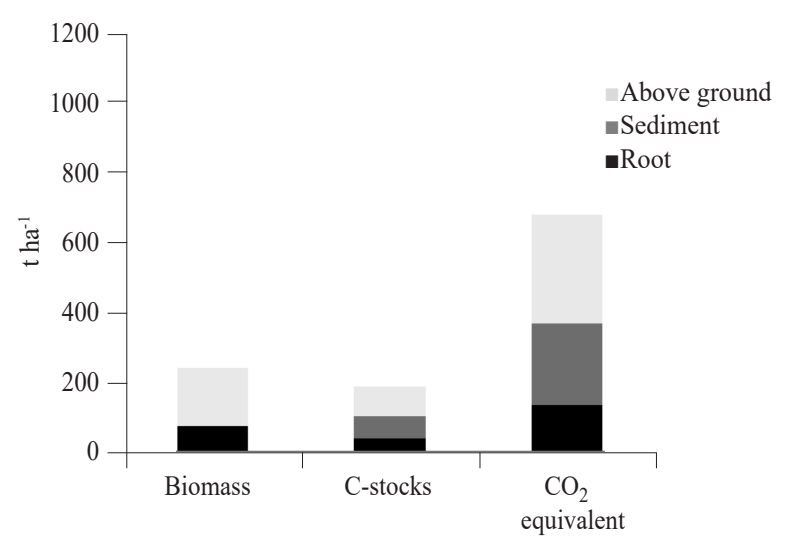

Fig. 7. Biomass, C-stocks and $\mathrm{CO}_{2}$ equivalent potential of the Kadalundi mangrove wetland

values obtained by Sahu et al. (2016) for A . officinalis, B. cylindrica and E. agallocha in the Mahanadi mangrove wetland along the east coast of India, our values for the same species were found to be much less. The higher above ground biomass $\left(140.05 \pm 23.25 \mathrm{t} \mathrm{ha}^{-1}\right)$ and root biomass $\left(56.43 \pm 8.51 \mathrm{t} \mathrm{ha}^{-1}\right)$ obtained in A. officinalis can also be attributed to the dense stem density when compared to other species recorded in the study area.

The overall mean AGB recorded during the study (166.63 $\mathrm{t} \mathrm{ha}^{-1}$ ) was much higher than that of the values obtained for the Rhizophora mangle forest of Puerto Rico (62.9 t ha ${ }^{-1}$, Golley et al., 1962), the forests of Avicennia marina var. resinifera in a flooded explosion crater in New Zealand (taller mangroves $104.1 \mathrm{tha}^{-1}$, low stunted mangroves $6.8 \mathrm{t} \mathrm{ha}^{-1}$; Woodroffe, 1985), the Manko Wetland, Okinawa, Japan (80.5 t ha-1, Khan et al., 2009), North Sulawesi (61.4 $\mathrm{t} \mathrm{ha}^{-1}$, Murdiyarso et al., 2009), the Sarawak Mangrove 
Table 5. Biomass and carbon stock of mangroves in different study stations along the Kadalundi Estuary

\begin{tabular}{|c|c|c|c|c|c|c|c|}
\hline \multirow{2}{*}{ Sectors } & \multirow{2}{*}{ Stations } & \multicolumn{2}{|c|}{ Above ground } & \multicolumn{2}{|c|}{ Below ground (Root) } & \multicolumn{2}{|c|}{ Total } \\
\hline & & $\begin{array}{l}\text { Biomass } \\
\left(\mathrm{t} \mathrm{ha}^{-1}\right)\end{array}$ & $\begin{array}{l}\text { Carbon } \\
\left(\mathrm{t} \mathrm{ha}^{-1}\right)\end{array}$ & $\begin{array}{l}\text { Biomass } \\
\left(\mathrm{t} \mathrm{ha}^{-1}\right)\end{array}$ & $\begin{array}{l}\text { Carbon } \\
\left(\mathrm{t} \mathrm{ha}^{-1}\right)\end{array}$ & $\begin{array}{l}\text { Biomass } \\
\left(\mathrm{t} \mathrm{ha}^{-1}\right)\end{array}$ & $\begin{array}{l}\text { Carbon } \\
\left(\mathrm{t} \mathrm{ha}^{-1}\right)\end{array}$ \\
\hline \multirow[t]{4}{*}{ Balathuruthi I } & 1 & 378.31 & 189.16 & 141.34 & 70.67 & 519.65 & 259.83 \\
\hline & 2 & 425.35 & 212.68 & 141.06 & 70.53 & 566.41 & 283.21 \\
\hline & 3 & 165.97 & 82.99 & 71.92 & 35.96 & 237.90 & 118.95 \\
\hline & 4 & 162.97 & 81.49 & 68.33 & 34.17 & 231.30 & 115.65 \\
\hline Mean & & 283.15 & 141.58 & 105.66 & 52.83 & 388.81 & 194.41 \\
\hline $\mathrm{SE}$ & & 69.19 & 34.60 & 20.53 & 10.26 & 89.56 & 44.78 \\
\hline \multirow[t]{5}{*}{ Balathuruthi II } & 1 & 212.84 & 106.42 & 91.84 & 45.92 & 304.67 & 152.34 \\
\hline & 2 & 192.35 & 96.18 & 74.87 & 37.44 & 267.23 & 133.61 \\
\hline & 3 & 344.46 & 172.23 & 173.02 & 86.51 & 517.48 & 258.74 \\
\hline & 4 & 237.84 & 118.92 & 94.84 & 47.42 & 332.67 & 166.34 \\
\hline & 5 & 181.82 & 90.91 & 92.51 & 46.26 & 274.33 & 137.17 \\
\hline Mean & & 233.86 & 116.93 & 105.42 & 52.71 & 339.28 & 169.64 \\
\hline $\mathrm{SE}$ & & 29.26 & 14.63 & 17.27 & 8.64 & 46.05 & 23.02 \\
\hline \multirow[t]{11}{*}{ Mannanthuruthi } & 1 & 162.45 & 81.22 & 64.72 & 32.36 & 227.17 & 113.58 \\
\hline & 2 & 20.82 & 10.41 & 10.22 & 5.11 & 31.05 & 15.52 \\
\hline & 3 & 82.05 & 41.02 & 36.70 & 18.35 & 118.75 & 59.38 \\
\hline & 4 & 124.01 & 62.00 & 53.94 & 26.97 & 177.95 & 88.97 \\
\hline & 5 & 37.09 & 18.55 & 20.09 & 10.04 & 57.18 & 28.59 \\
\hline & 6 & 116.35 & 58.17 & 53.66 & 26.83 & 170.01 & 85.00 \\
\hline & 7 & 102.09 & 51.05 & 50.46 & 25.23 & 152.55 & 76.28 \\
\hline & 8 & 257.76 & 128.88 & 104.24 & 52.12 & 361.99 & 180.99 \\
\hline & 9 & 194.44 & 97.22 & 81.63 & 40.82 & 276.08 & 138.04 \\
\hline & 10 & 99.01 & 49.51 & 44.38 & 22.19 & 143.40 & 71.70 \\
\hline & 11 & 143.64 & 71.82 & 59.59 & 29.79 & 203.23 & 101.61 \\
\hline Mean & & 121.79 & 60.90 & 52.69 & 26.35 & 174.49 & 87.24 \\
\hline $\mathrm{SE}$ & & 20.40 & 10.20 & 7.91 & 3.96 & 28.29 & 14.14 \\
\hline \multirow[t]{4}{*}{ West of railway bridge } & 1 & 97.87 & 48.93 & 39.10 & 19.55 & 136.97 & 68.48 \\
\hline & 2 & 220.02 & 110.01 & 88.23 & 44.12 & 308.25 & 154.12 \\
\hline & 3 & 23.34 & 11.68 & 12.22 & 6.11 & 35.58 & 17.79 \\
\hline & 4 & 16.31 & 8.15 & 9.27 & 4.64 & 25.58 & 12.79 \\
\hline Mean & & 89.39 & 44.69 & 37.21 & 18.60 & 126.59 & 63.30 \\
\hline Standard error & & 47.29 & 23.64 & 18.28 & 9.14 & 65.57 & 32.78 \\
\hline Overall mean & & 166.63 & 83.32 & 69.92 & 34.96 & 236.56 & 118.28 \\
\hline Standard error & & 22.12 & 11.06 & 8.61 & 4.30 & 30.53 & 15.26 \\
\hline
\end{tabular}

Forest, Malaysia (116.8 $\mathrm{t} \mathrm{ha}^{-1}$, Chandra et al., 2011) and the estuarine complex along the Bay of Bengal, India (60 to $117.7 \mathrm{t} \mathrm{ha}^{-1}$, Kathiresan et al., 2013). The present AGB values were almost comparable with the mean AGB values obtained for Rhizophora apiculata mangroves in Thailand (159 t ha ${ }^{-1}$, Christisen, 1978) and for the mangrove forests of Mahanadi Mangrove Wetland, India (natural mangrove stands $124.91 \mathrm{t} \mathrm{ha}^{-1}$, plantation mangrove stands $125.55 \mathrm{t} \mathrm{ha}^{-1}$; Sahu et al., 2016). The findings in the Kadalundi wetland was lower than the above-ground biomass obtained for the Micronesian mangroves (363 $\mathrm{t} \mathrm{ha}^{-1}$ at Yap, $225 \mathrm{t} \mathrm{ha}^{-1}$ at Palau;
Kauffman et al., 2011). While comparing the results of the Kadalundi wetland with other mangrove areas, it is evident that the above-ground biomass varies greatly from region to region. The biomass is determined by various factors such as species composition, tree density, growth forms, tree height, stem diameter and age of the mangrove stands (Lugo and Snedaker, 1974; Woodroffe, 1985; Knox, 1986). The mangrove stands of Kadalundi has well established 30 to 40 year-old predominant population of A. officinalis which has contributed significantly to the mean above-ground biomass of $166.63 \mathrm{tha}^{-1}$. 
Table 6. Soil organic carbon pools of the Kadalundi mangrove wetland

\begin{tabular}{|c|c|c|c|c|}
\hline Sectors & Stations & Bulk density $\left(\mathrm{g} \mathrm{cm}^{-3}\right)$ & Percentage sediment organic Carbon & Sediment organic Carbon $\left(\mathrm{t} \mathrm{ha}^{-1}\right)$ \\
\hline \multirow[t]{4}{*}{ Balathuruthi I } & 1 & 0.75 & 2.90 & 65.25 \\
\hline & 2 & 1.19 & 0.57 & 20.35 \\
\hline & 3 & 0.59 & 1.00 & 17.70 \\
\hline & 4 & 0.60 & 3.18 & 57.24 \\
\hline Mean & & 0.78 & 1.91 & 40.13 \\
\hline SE & & 0.14 & 0.66 & 12.31 \\
\hline \multirow[t]{5}{*}{ Balathuruthi II } & 1 & 0.65 & 4.32 & 84.24 \\
\hline & 2 & 0.85 & 3.84 & 97.92 \\
\hline & 3 & 0.69 & 3.26 & 67.48 \\
\hline & 4 & 0.96 & 2.43 & 69.98 \\
\hline & 5 & 0.76 & 2.73 & 62.24 \\
\hline Mean & & 0.78 & 3.31 & 76.37 \\
\hline SEE & & 0.06 & 0.35 & 6.50 \\
\hline \multirow[t]{11}{*}{ Mannanthuruthi } & 1 & 0.90 & 1.52 & 41.04 \\
\hline & 2 & 1.20 & 2.19 & 78.84 \\
\hline & 3 & 0.52 & 4.06 & 63.34 \\
\hline & 4 & 1.00 & 1.22 & 36.60 \\
\hline & 5 & 0.83 & 2.86 & 71.21 \\
\hline & 6 & 0.73 & 2.64 & 57.82 \\
\hline & 7 & 0.75 & 3.37 & 75.83 \\
\hline & 8 & 0.69 & 4.03 & 83.42 \\
\hline & 9 & 0.84 & 3.03 & 76.36 \\
\hline & 10 & 1.03 & 2.98 & 92.08 \\
\hline & 11 & 1.08 & 3.78 & 122.47 \\
\hline Mean & & 0.87 & 2.88 & 72.64 \\
\hline $\mathrm{SE}$ & & 0.06 & 0.29 & 7.16 \\
\hline \multirow{4}{*}{$\begin{array}{l}\text { West of railway } \\
\text { bridge }\end{array}$} & 1 & 1.01 & 2.18 & 66.05 \\
\hline & 2 & 1.14 & 2.61 & 89.26 \\
\hline & 3 & 1.45 & 1.08 & 46.98 \\
\hline & 4 & 1.91 & 1.10 & 63.03 \\
\hline Mean & & 1.38 & 1.74 & 66.33 \\
\hline SE & & 0.20 & 0.39 & 8.71 \\
\hline Overall Mean & & 0.95 & 2.62 & 63.87 \\
\hline $\mathrm{SE}$ & & 0.12 & 0.22 & 8.67 \\
\hline
\end{tabular}

The carbon pools of AGB estimated by Kauffman et al. (2011) in the Micronesian mangrove forests (104.4 $\mathrm{t} \mathrm{ha}^{-1}$ at Palau and $169.2 \mathrm{t} \mathrm{ha}^{-1}$ at Yap) was much higher than the above-ground carbon pools of the present study (83.32 $\left.\mathrm{t} \mathrm{C} \mathrm{ha-1}^{-1}\right)$. The present values of above-ground C-stock were, however, higher when compared to the values estimated by Chen et al. (2012) in Southern China $\left(55 \mathrm{t} \mathrm{ha}^{-1}\right)$ and by Sahu et al. (2016) in the natural stands of the Mahanadi Mangrove Wetland, India (62.45 $\left.\mathrm{t} \mathrm{ha}^{-1}\right)$.

The overall mean root biomass $\left(69.92 \pm 8.61 \mathrm{t} \mathrm{ha}^{-1}\right)$ and C-stock of root biomass $\left(34.96 \pm 4.30 \mathrm{t} \mathrm{C} \mathrm{ha-1}^{-1}\right)$ obtained for the Kadalundi mangrove wetland were found to be less when compared to the values obtained in Yap (root biomass of 312 tha $^{-1}$ and C-stock of $144 \mathrm{t} \mathrm{C} \mathrm{ha}^{-1}$; Kauffman et al.,
2011). However, the present study showed comparatively higher $\mathrm{C}$-stock than the mangroves of southern China (21.4 t C ha-1, Chen et al., 2012), Tamil Nadu, India (18.1-12.9 t C ha-1, Kathiresan et al., 2013) and the Mahanadi Mangrove Wetland, India (27.86 26.69 t C ha ${ }^{-1}$ for natural stands and $27.86 \mathrm{t} \mathrm{C} \mathrm{ha}^{-1}$ for plantation stands; Sahu et al., 2016).

In the present study, the ratio of above-ground biomass and root biomass was 2.38 (average). The results obtained in Kadalundi was consistent with the values of Komiyama et al. (2008) which varied from 1.1 to 4.4. The present values were also comparable with that of the mangroves of Mahanadi, India (T/R ratio of 2.3; Sahu et al. 2016). Komiyama et al. (2008) concluded that the 
$T / R$ ratio of mangroves is significantly lower than the terrestrial forests, since a large amount of biomass gets allocated to the root system of the mangroves which helps the mangrove trees to stand upright in soft and wet muddy conditions.

The average sediment organic carbon $(63.87 \pm 8.67 \mathrm{t}$ $\mathrm{C} \mathrm{ha}^{-1}$ ) obtained for Kadalundi wetland was lower than the values obtained for the same depth in the Micronesian mangroves (Palau 128.1 t C ha-1, Yap 119.5 t C ha-1; Kauffman et al., 2011), but higher than the Mahanadi Mangrove Wetland, India (57.6 t C ha'-1; Sahu et al., 2016). Our findings were also substantially higher compared to the sediment $\mathrm{C}$-stock values obtained at $1 \mathrm{~m}$ depth in Okinawa, Japan (57.3 t C ha-1; Khan et al., 2007), but much lower than the value obtained for the sediment collected from $1.22 \mathrm{~m}$ depth in North Sulawesi, Indonesia (Murdiyarso et al., 2009).

The sediments in a mangrove area serve as an important carbon pool (Donato et al., 2011; Kauffman et al., 2011; Kauffman and Donato, 2012) and this has been proven in the Kadalundi wetland also as the estimated sediment C-stock was $35.06 \%$ of the total C-stock. The mean sediment $\mathrm{C}$-stock obtained in the present study was equivalent to $234.40 \mathrm{t} \mathrm{CO}_{2} \mathrm{ha}^{-1}$. The present study, which estimated the sediment $\mathrm{C}$-stock in the upper $30 \mathrm{~cm}$ depth, is only indicative of the potential of mangrove sediments to act as carbon reservoirs. However, studies on the presence of carbon at different sediment depths are important in view of the blue carbon trading (Nellemann et al., 2009; Lawrence, 2012).

The mangroves in the Kadalundi wetland cover an area of 13.23 ha and we assume that this area has a potential to sequester and store a substantial quantity of 2,409.84 t C, equivalent to an estimated amount of 8,844.11 t $\mathrm{CO}_{2}$. Moore and Diaz (2015) computed the social cost of carbon (SCC) as US \$220 per ton of $\mathrm{CO}_{2}$ which corresponds to ₹ 14,250 per ton. The estimated SCC for the Kadalundi wetland is ₹126.02 million. The present study, thus, underscores the importance of these intertidal forests in the light of climate change mitigation and stresses the importance of protecting mangroves which also provide many other important ecosystem services and functions that benefit the communities. Worldwide, attention is now paid for the protection and restoration of mangroves, realising their importance in storing carbon in their plant parts as well as in sediment, thereby acting as blue carbon sink.

Being a part of the community reserve, the mangroves of Kadalundi are well protected from anthropogenic destructions as the communities living along the
Kadalundi wetland have a deep concern for the protection of mangroves. However, accretion of sand on the western edge of this wetland, close to the bar mouth, has been a serious threat to the mangrove stands, resulting in the smothering of roots and consequent death of some trees of S. alba and A. officinalis (Fig. 8). For the rehabilitation of mangrove areas affected by sand accretion, Ellison (1998) suggested that elevation changes must be assessed in the selection of species for replanting where the disturbance was a past event and field trials are required in areas where rapid accretion is an ongoing problem. We found that sand accretion is an ongoing process in the Kadalundi wetland; particularly near the bar mouth and therefore, more studies are suggested to tackle this problem. Suitable management measures need to be adopted to protect the rich mangrove wealth of the Kadalundi wetland, coupled with mangrove plantation efforts in suitable areas in order to sequester and store more carbon.

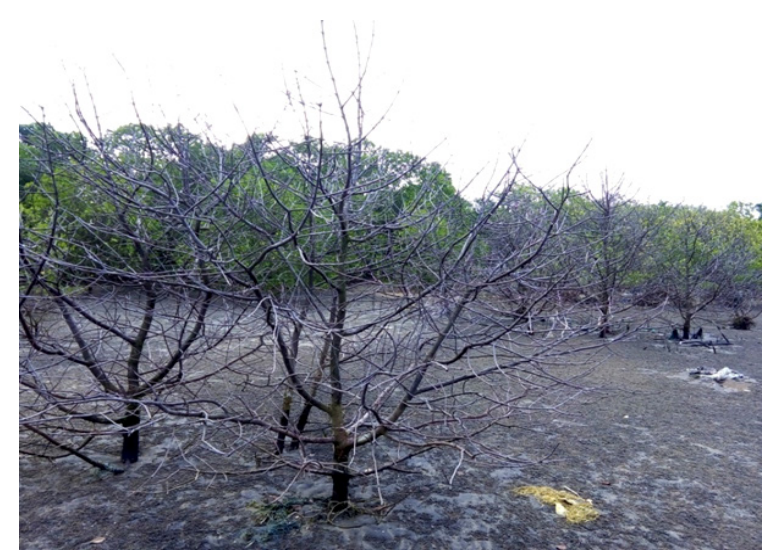

Fig. 8. Accretion of sand resulting in wilting of Sonneratia alba in the western side of the estuarine wetland

\section{Acknowledgements}

The authors express their profound gratitude to Dr. A. Gopalakrishnan, Director, ICAR-CMFRI, Kochi, India, for providing facilities and support. The research work was carried out under the Project, 'National Innovations in Climate Resilient Agriculture', of the Indian Council of Agricultural Research, Government of India.

\section{References}

Alongi, D. M., Tirendi, F. and Clough, B. F. 2000. Below-ground decomposition of organic matter in forests of the mangroves Rhizophora stylosa and Avicennia marina along the arid coast of Western Australia. Aquat. Bot., 68: 97-122.

Barbier, E. B. 2000. Valuing the environment as input: Review of applications to mangrove-fishery linkages. Ecol. Econ., 35: 47-61. 
Chandra, I. A., Seca, G. and Abu Hena, M. K. 2011. Above ground biomass production of Rhizophora apiculata Blume in Sarawak mangrove forest. Am. j. J. Agri. Biol. Sci., 6: 469-474.

Chen, L., Zeng, X., Tam, N. F. Y., Lu, W., Luo, Z., Du, X. and Wang, J. 2012. Comparing carbon sequestration and stand structure of monoculture and mixed mangrove plantations of Sonneratia caseolaris and $S$. apetala in southern China. Forest Ecol. Manag., 284: 222-229.

Christisen, B. 1978. Biomass and primary production of Rhizophora apiculata B1. in a mangrove in Southern Thailand. Aquat. Bot., 4: 43-52.

Clark, D. A., Brown, S., Kicklighter, D. W., Chamber, J. Q., Thomlinson, J. R., Ni, J. and Holland, E. A. 2001. Net primary production in tropical forests: An evaluation and synthesis of existing field data. Ecol. Appl., 11: 371-384.

Diele, K., Koch, V. and Saint-Paul, U. 2005. Population structure and catch composition of the exploited mangrove crab Ucides cordatus in the Cacte Estuary, North Brazil: indications of overfishing? Aquat. Living Res., 18: 169-178.

Donato, D. C., Boone Kauffman, J., Murdiyarso, D., Kurnianto, S., Stidham, M. and Kanninen, M. 2011. Mangroves among the most carbon-rich forests in the tropics. Nat. Geosci., 4: 293-297.

Ellison, J. C. 1998. Impacts of sediment burial on mangroves. Mar. Pollut. Bull., 37(8-12): 420-426.

Field, C. D. 1995. Impact of expected climate change on mangroves. Hydrobiologia, 295: 75-81.

Frontier Madagascar 2005. A field manual for survey methods in tropical marine ecosystems. In: Biddick, K., Brown, L. F., Markham, K., Mayhew, E. M., Robertson, A. and Smith, V. (Eds.), Frontier Madagascar environmental research report 17, Society for Environmental Exploration, UK.

FSI 2013. State of forest report 2013. Forest Survey of India, Dehradun, India.

Giri, C., Ochieng, E., Tieszen, L. L., Zhu, Z., Singh, A., Loveland, T., Masek, J. and Duke, N. 2011. Status and distribution of mangrove forests of the world using earth observation satellite data. Global Ecol. Biogeogr., 20: 154-159.

Golley, F. B., Odum, H. T. and Wilson, R. F. 1962. The structure and metabolism of a Puerto Rican red mangrove forest in May. Ecology, 43: 9-19.

Kathiresan, K., Anburaj, R., Gomathi, V. and Saravanakumar, K. 2013. Carbon sequestration potential of Rhizophora mucronata and Avicennia marina as influenced by age, season, growth and sediment characteristics in south-east coast of India. J. Coast. Conserv., 17: 397-408.

Kauffman, J. B., Heider, C., Cole, T. G., Dwire, K. A. and Donato, D. C. 2011. Ecosystem carbon stocks of Micronesian mangrove forests. Wetlands, 31:343-352.

Kauffman, J. B. and Donato, D. C. 2012. Protocols for the measurement, monitoring and reporting of structure, biomass and carbon stocks in mangrove forests. Working
Paper 86, Centre for International Forestry Research, (CIFOR), Bogor, Indonesia, 40 pp.

Khan, M. N. I., Suwa R. and Hagihara, A. 2007. Carbon and nitrogen pools in a mangrove stand of Kandelia obovata (S. L.) Yong: vertical distribution in the soil-vegetation system. Wetl. Ecol. Manag., 15(2): 141-153.

Khan, M. N. I., Suwa, R. and Hagihara, A. 2009. Biomass and aboveground net primary production in a subtropical mangrove stand of Kandelia obovata (S. L.) Yong at Manko Wetland, Okinawa, Japan. Wetl. Ecol. Manag., 17: 585-599.

Knox, G. A. 1986. Estuarine ecosystems: A system approach, vol. I. CRC Press, Florida.

Komiyama, A., Poungparn, S. and Kato, S. 2005. Common allometric equations for estimating the tree height of mangroves. J. Trop. Ecol., 21: 471-477.

Komiyama, A., Ong, J. E. and Poungpam, S. 2008. Allometry, biomass and productivity of mangrove forests: a review. Aquat. Bot., 89: 128-137.

Lawrence, A. 2012. Blue carbon: a new concept for reducing the impacts of climate change by conserving coastal ecosystems in the coral triangle. WWF-Australia, Brisbane, Queensland, $21 \mathrm{pp}$.

Lugo, A. E. and Snedaker, S. C. 1974. The ecology of mangroves. Ann. Rev. Ecol. Syst., 5: 39-64.

Machiwa, J. F. and Hallberg, R. O. 2002. An empirical model of the fate of organic carbon in a mangrove forest partly affected by anthropogenic activity. Ecol. Model., 147: 69-83.

Malhi, Y. and Grace, J. 2000. Tropical forests and atmospheric carbon dioxide. Trends Ecol.Evol.,15: 332-337.

Moore, F. C and Diaz, D. B. 2015. Temperature impacts on economic growth warrant stringent mitigation policy. Nat. Clim. Change, 5: 127-131.

Mumby,P.J.,Edwards, A. J.,Arias-Gonzalez, J.E., Lindeman, K.C., Blackwell, P. G., Gall, A., Gorczynska, M. I., Harborne, A. R., Pescod, C. L., Renken, H., Wabnitz, C. C. C. and Llewellyn, G. 2004. Mangroves enhance the biomass of coral reef fish communities in the Caribbean. Nature, 427: 533-536.

Murdiyarso, D., Donato, D., Kauffman, J. B., Kurnianto, S., Stidham M. and Kanninen, M. 2009. Carbon storage in mangrove and peatland ecosystems in Indonesia - a preliminary account from plots in Indonesia. Working Paper 48, Center for International Forestry Research, Bogor, Indonesia, $35 \mathrm{pp}$.

Nellemann, C., Corcoran, E., Duarte, C.M., Valdes, L., De Young, C., Fonseca, L. and Grimsditch, G. 2009. Blue carbon: the role of healthy oceans in binding carbon. A rapid response assessment. United Nations Environment Programme, Birkelandn Trykkeri AS, Norway, 80 pp.

Rivera-Monroy, V. H., Torres, I. A., Bahamon, N., Newmark, F. and Twilley, R. R. 1999. The potential use of mangrove forests as nitrogen sinks of shrimp aquaculture pond 
effluents: The role of denitrification. J. World Aquacult. Soc., 30(1): 12-25.

Robertson, A. I. and Phillips, M. J. 1995. Mangroves as filters of shrimp pond effluent: Predictions and biogeochemical research needs. Hydrobiologia, 295: 311-321.

Sahu, S. C., Manish Kumar and Ravindranath, N. H. 2016. Carbon stocks in natural and planted mangrove forests of Mahanadi Mangrove Wetland, East coast of India. Curr. Sci., 110(12): $2253-2260$

Twilley, R. R., Chen, R. H. and Hargis, T. 1992. Carbon sinks in mangrove forests and their implications to the carbon budget of tropical coastal ecosystems. Water Air Soil Poll., 64(1): 265-288.
Walkley, A. and Black, I. A. 1934. An examination of Degtjareff method for determining soil organic matter and a proposed modification of the chromic acid titration method. Soil Sci., 37: 29-37.

Woodroffe, C. D. 1985. Studies of a mangrove basin, Tuff Crater, New Zealand. I: mangrove biomass and production of detritus. Estuar. Coast. Shelf Sci., 20: 265-280.

WFC 2011. World Agroforestry Database, World Agroforestry Centre, Nairobi, Kenya. http://www.worldagroforestry centre.org/our_products/databases (Accessed 11 May 2011). 